\title{
Numerical Analysis of a Real Photovoltaic Module with Various Parameters
}

\author{
Costica Nituca, ${ }^{1}$ Gabriel Chiriac $\mathbb{D}^{1},{ }^{1}$ Dumitru Cuciureanu, ${ }^{2}$ \\ Guoqiang Zhang, ${ }^{3}$ Dong Han, ${ }^{3}$ and Adrian Plesca ${ }^{1}$ \\ ${ }^{1}$ Faculty of Electrical Engineering, "Gheorghe Asachi” Technical University of Iasi, Profesor Dimitrie Mangeron, \\ No. 23, 700050 Iasi, Romania \\ ${ }^{2}$ Q SRL, Stradela Sfantul Andrei, No. 13, Iasi, Romania \\ ${ }^{3}$ Institute of Electrical Engineering, Chinese Academy of Sciences, No. 6, Beiertiao, Zhongguancun, Beijing, China
}

Correspondence should be addressed to Gabriel Chiriac; gchiriac@tuiasi.ro

Received 19 December 2017; Accepted 29 January 2018; Published 20 March 2018

Academic Editor: Ricardo Perera

Copyright (C) 2018 Costica Nituca et al. This is an open access article distributed under the Creative Commons Attribution License, which permits unrestricted use, distribution, and reproduction in any medium, provided the original work is properly cited.

\begin{abstract}
This article presents a real photovoltaic module with modeling and simulations starting from the model of a photovoltaic (PV) cell. $I-V, P-V$, and $P-I$ characteristics are simulated for different solar irradiation, temperatures, series resistances, and parallel resistances. For a real photovoltaic module (ALTIUS Module AFP-235W) there are estimated series and parallel resistances for which the energetical performances of the module have optimal values for a solar radiation of $1000 \mathrm{~W} / \mathrm{m}^{2}$ and a temperature of the environment of $25^{\circ} \mathrm{C}$. Temperature influence over the PV module performances is analyzed by using a thermal model of the ALTIUS Module AFP-235W using the finite element method. A temperature variation on the surface of the PV module is starting from a low value $40.15^{\circ} \mathrm{C}$ to a high value of $52.07^{\circ} \mathrm{C}$. Current and power estimation are within the errors from $1.55 \%$ to about $4.3 \%$. Experimental data are measured for the photovoltaic ALTIUS Module AFP-235W for an entire daylight.
\end{abstract}

\section{Introduction}

Solar energy is a renewable and no pollution energy with a significant annual riseup and this trend follows an ascending path. Locally produced renewable energy is more and more promoted as a key to the affordable and sustainable energy in remote area, in small communities, or for small consumers even into the large cities. Photovoltaic systems are realized form photovoltaic (PV) cells; one of the major advantages of photovoltaic cells is that they are highly modular and by proper scaling, they can be expected to provide adequate power for various loads [1]. These cells depend on photovoltaic effect for converting solar radiation into electricity and the generated photocurrent is proportional to the solar irradiation [2]. The output characteristics of a PV cell are nonlinear and fluctuate with solar radiation, cell temperature, series and parallel resistance, and other parameters of the mathematical model [3].

The modeling and simulation of the photovoltaic modules began long ago, but improvements of these models are analyzed and presented continually $[2,4-6]$. The implementation of mathematical model of photovoltaic cell into specialized software MATLAB-Simulink is widely used. The computing models are realized by using the equations for the parameters as thermal voltage, photovoltaic current, diode saturation current, and ideality factor. The main characteristics can be obtained, such as the current-voltage $(I-V)$ and powervoltage $(P-V)$ characteristics $[1,4,7-10]$. The series and parallel resistances have an important influence over the PV cell parameters and these resistances are considered into the mathematical models, but in some cases [11-13] the series resistance is neglected into the model and in some cases [1317] the parallel resistance is neglected. Thermal analysis of the photovoltaic panels is an important part of the studies in order to estimate the temperature distribution in a $\mathrm{PV}$ module and to determine the operating temperature of solar system accurately. Optical parameters for the reflectivity, transmissivity, and absorptivity for the relevant layers of the module are taken into account to determine the heat dissipation in the areas exposed directly to sunlight. Heat losses by convection and radiation are also included in simulations [18]. Finite element analysis is considered by 


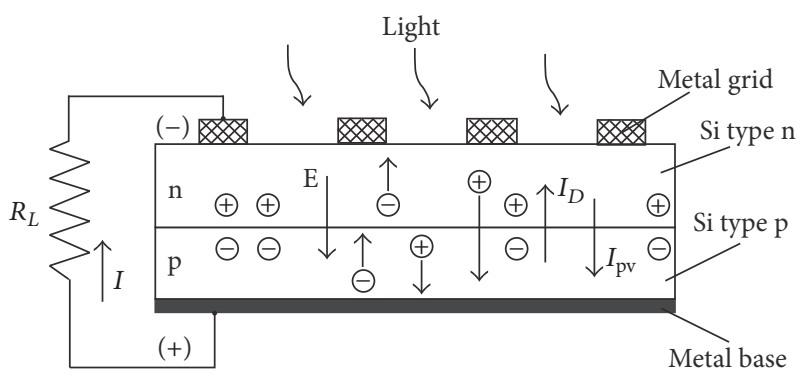

FIgUre 1: Physical structure of the photovoltaic cell.

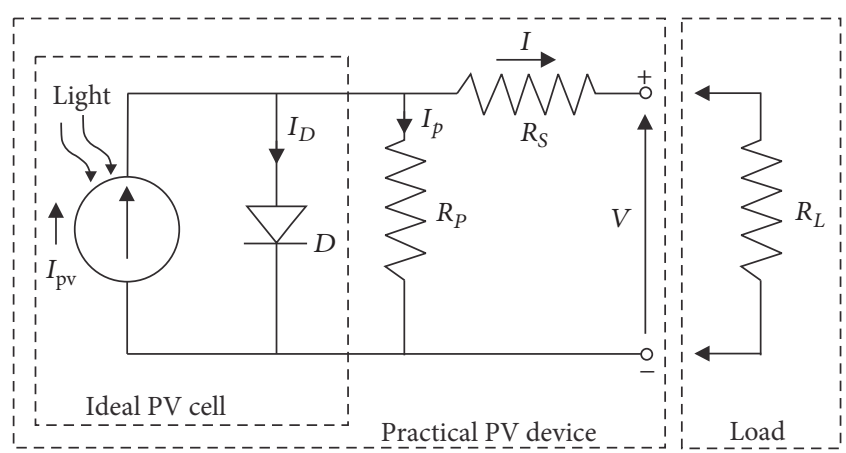

FIgURE 2: Equivalent model of a PV cell.

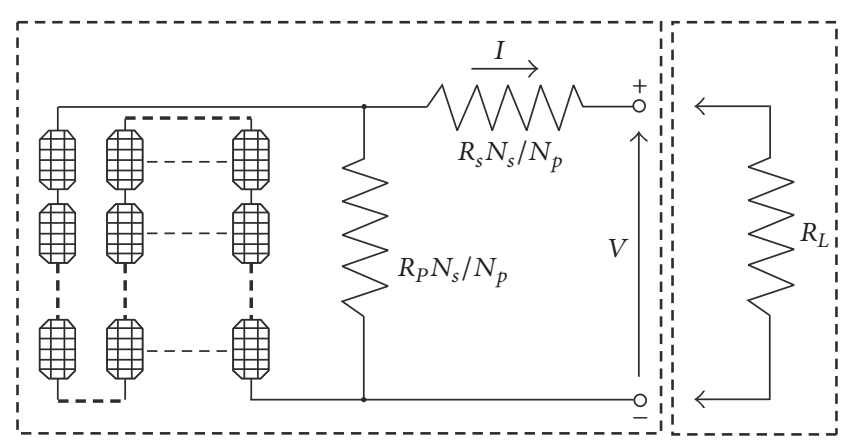

FIGURE 3: The PV module equivalent circuit model. thermal simulation is also realized. There are also some experimental data analyzed and registered for an ALTIUS 235 module which is in regular use. The authors outline the variation of main electrical characteristics of a real PV module depending on solar radiation and also the correlation of the suitable functionality of the PV module with the temperature.

\section{Modeling the Photovoltaic Module}

2.1. Ideal PV Cell. The photovoltaic (PV) cell is considered as a semiconductor diode which is exposed to the solar radiation (Figure 1). A part of this radiation is absorbed by the $p n$ junction creating pairs of electron hole. These electrical charges are separated by the electric field E: the electrons migrate in the " $n$ " area and the holes migrate in the " $p$ " area. This separation is the photovoltaic effect and it generates an electric current. This situation can be modeled into a simplified model having a current source in parallel with an ideal diode, with a photovoltaic current $I_{\mathrm{pv}}$ and a diode current $I_{D}$. Practical aspects of the PV cell can be studied considering a single-diode PV model with a series resistance $R_{s}$ and a parallel resistance $R_{p}$ (Figure 2).

The main equations to describe the $I-V$ characteristics of an ideal PV cell are $[1,4,7]$

$$
\begin{aligned}
I & =I_{\mathrm{pv}}-I_{D} \\
I_{D} & =I_{0}\left[\exp \left(\frac{q V}{a k T}-1\right)\right], \\
I & =I_{\mathrm{pv}}-I_{0}\left[\exp \left(\frac{q V}{a k T}\right)-1\right] .
\end{aligned}
$$

2.2. Modeling the PV Module. Many researches $[1,5,9,10]$ show that, for the analysis of the PV cells, there are some necessary supplementary parameters to be used into (3):

$$
I=I_{\mathrm{pv}}-I_{0}\left[\exp \left(\frac{V+R_{s} I}{a V_{T}}\right)-1\right]-\frac{V+R_{s} I}{R_{p}},
$$

where

$$
V_{T}=\frac{k T}{q}
$$

In order to assure the parameters required on the consumers, a photovoltaic system has to be made by a sufficient number of PV cells, connected in series or in parallel, usually called modules or arrays. Figure 3 presents the equivalent circuit model of a photovoltaic system.

For the structure module in Figure 3, (4) will be [5, 8]

$$
\begin{aligned}
I= & I_{\mathrm{pv}} N_{p}-I_{0} N_{p}\left[\exp \left(\frac{V+I R_{s}\left(N_{s} / N_{p}\right)}{a V_{T} N_{s}}\right)-1\right] \\
& -\frac{V+I R_{s}\left(N_{s} / N_{p}\right)}{R_{p}\left(N_{s} / N_{p}\right)} .
\end{aligned}
$$

Based on the same characteristic, the following items are to be considered as well: the open circuit voltage/temperature coefficient $\left(K_{V}\right)$, the short circuit current/temperature coefficient $\left(K_{I}\right)$, and the maximum experimental peak output power $\left(P_{\max , e}\right)[5]$. These aspects are related to the nominal condition 


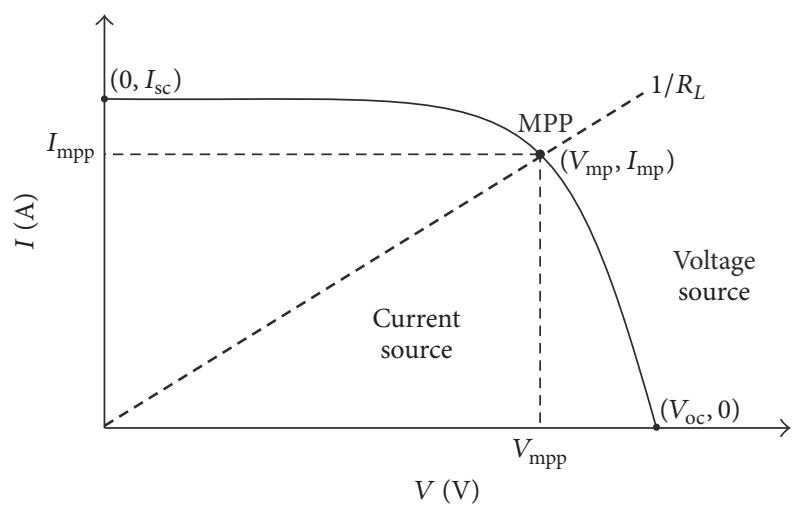

Figure 4: $I-V$ characteristic of a practical photovoltaic device.

or to the Standard Test Conditions (STC). In these conditions the photovoltaic device has series resistances $R_{s}$ with a strong impact when the system operates in the voltage source area and a parallel resistance $R_{p}$ with a strong influence when the system operates in the current source area. In some cases [1113 ] the $R_{s}$ resistance is neglected into the model and in some cases [13-17] the $R_{p}$ resistance is neglected.

For some points on the characteristic in Figure 4 (the short circuit $\left(0, I_{\mathrm{sc}}\right)$, open circuit $\left(V_{0 c}, 0\right)$, and Maximum Power Point $\left.\left(V_{\mathrm{mpp}}, I_{\mathrm{mpp}}\right)\right)$, the relations it can be written as follows[9]:

$$
\begin{aligned}
0 & =I_{\mathrm{pv}, n}-I_{0, n}\left[\exp \left(\frac{V_{0 c, n}}{V_{T, n}}\right)-1\right], \\
I_{\mathrm{mpp}, n} & =I_{\mathrm{pv}, n}-I_{0, n}\left[\exp \left(\frac{V_{\mathrm{mpp}, n}+R_{s} I_{\mathrm{mpp}, n}}{V_{T, n}}\right)-1\right] .
\end{aligned}
$$

The current generated by the photovoltaic panel depends directly on the solar irradiation and is influenced by the temperature according to the next relation $[26,27]$ :

$$
I_{\mathrm{pv}}=\left(I_{\mathrm{pv}, n}+K_{I} \Delta T\right) \frac{G}{G_{n}},
$$

where

$$
\Delta T=T-T_{n}
$$

The nominal open voltage can be influenced by the temperature according to the relation [14]:

$$
V_{0 c}=V_{0 c, n}\left(1+K_{V} \Delta T\right)+V_{T} \ln \left(\frac{G}{G_{n}}\right) .
$$

The saturation current of the diode depends also on the temperature $[5,28,29]$ :

$$
I_{0}=I_{0, n}\left(\frac{T_{n}}{T}\right)^{3} \exp \left[\frac{q E_{g}}{a k}\left(\frac{1}{T_{n}}-\frac{1}{T}\right)\right],
$$

where $E_{g}$ is the band gap energy of the semiconductor $\left(E_{g}\right.$ $=1.12 \mathrm{eV}$ for the polycrystalline $\mathrm{Si}$ at $25^{\circ} \mathrm{C}$ ). The value of the saturated nominal current is given by [5]

$$
I_{0, n}=\frac{I_{\mathrm{sc}, n}}{\exp \left(V_{0 c, n} / a V_{T, n}\right)-1} \text {. }
$$

Some researches $[5,30,31]$ suggest an improving of the saturation current on the diode established by (10). The current $I_{\mathrm{pv}, n}$ can be assumed to be approximately equal to $I_{\mathrm{sc}}$, which is a very common assumption in PV modeling [5]. The assumption gives a good approximation because the series resistance is usually very small and the parallel resistance is large $[5,10]$. In these conditions the saturation current on diode becomes

$$
I_{0}=\frac{I_{\mathrm{sc}, n}+K_{I} \Delta T}{\exp \left(\left(V_{0 c, n}+K_{V} \Delta T\right) / a N_{c} V_{t}\right)-1} .
$$

The performances of a PV cell depend also on the fill factor (FF), which is the ratio between the Maximum Power of a cell and the power of an ideal PV cell in the same operating conditions.

For a variable resistive load $R_{L}$ connected at the cell output the power will be at maximum when the resistance $R_{L}$ will have an optimal value $R_{\text {Lopt }}$ equal to the ratio between the voltage $V_{\mathrm{mpp}}$ and the current $I_{\mathrm{mpp}}$, Figure 4 . Thus, the theoretical Maximum Power generated by the PV cell will be equal to the product between the $V_{\mathrm{oc}}$ and $I_{\mathrm{sc}}$.

In these conditions, the fill factor (FF) is defined by

$$
\mathrm{FF}=\frac{P_{\mathrm{max}, e}}{I_{\mathrm{sc}} V_{\mathrm{oc}}}=\frac{I_{\mathrm{mpp}} V_{\mathrm{mpp}}}{I_{\mathrm{sc}} V_{\mathrm{oc}}} .
$$

The efficiency is calculated as the ratio between the power in MPP (for a specific temperature) and the power of the solar irradiation:

$$
\eta=\frac{P_{\mathrm{mpp}}}{A_{\text {cell }} G} .
$$

\section{The Effect of the Series and Parallel Resistances on the PV Cell Performances}

The series and parallel resistances $\left(R_{s}\right.$ and $\left.R_{p}\right)$ have an important influence on the fill factor FF decreasing. Its value will decrease with $R_{s}$ increasing and $R_{p}$ decreasing. It is noteworthy that the series resistance $R_{s}$ depends mainly on the internal resistances of the semiconductor devices, on the contact resistances, and on the electrical wires resistances and it has to be as low as possible. In the same time, the parallel resistance $R_{p}$ depends on the metallic bridges between the edges of the junction, on the material defects (where losses' currents can appear, which can short-circuit the $p n$ junction). Usually, its value is high, from thousands to tenth of thousands of ohms.

The relation between $R_{s}$ and $R_{p}$ can be estimated starting from the equality $P_{\max , m}=P_{\max , e}$, resulting in the relation for the resistance $R_{p}[5,10]$ : 


$$
\begin{aligned}
P_{\mathrm{mac}, m} & =V_{\mathrm{mpp}}\left\{I_{\mathrm{pv}}-I_{0}\left[\exp \left(\frac{q}{k T} \frac{V_{\mathrm{mpp}}+R_{s} I_{\mathrm{mpp}}}{a N_{s}}\right)-1\right]-\frac{V_{\mathrm{mpp}}+R_{s} I_{\mathrm{mpp}}}{R_{p}}\right\}=P_{\mathrm{max}, e} \\
R_{p} & =\frac{V_{\mathrm{mpp}}+I_{\mathrm{mpp}} R_{s}}{\left\{I_{\mathrm{pv}} V_{\mathrm{mpp}}-I_{0} V_{\mathrm{mpp}} \exp \left[(q / k T)\left(\left(V_{\mathrm{mpp}}+I_{\mathrm{mpp}} R_{s}\right) / a N_{s}\right)\right]+I_{0} V_{\mathrm{mpp}}-P_{\mathrm{max}, e}\right\}} .
\end{aligned}
$$

This equation is solved by successive iterations until it results in the best solution for the PV device. The solution has to concede with the maximum of the points $V_{\mathrm{mpp}}$ and $I_{\mathrm{mpp}}$, on the $I-V$ characteristic (Figure 4 ). In these conditions, the following with be the results [10]:

$$
\mathrm{I}_{\mathrm{pv}, n}=\frac{R_{p}+R_{s}}{R_{p}} I_{\mathrm{sc}, n} .
$$

The initial value for $R_{s}$ is considered as zero, while the value for $R_{p}$ is given by [7]

$$
R_{p, \min }=\frac{V_{\mathrm{mpp}}}{I_{\mathrm{sc}, n}-I_{\mathrm{mpp}}}-\frac{V_{0 c, n}-V_{\mathrm{mpp}}}{I_{\mathrm{mpp}}} .
$$

\section{Numerical Modeling and Simulations of a Real Photovoltaic Module}

Using the parameters of the ALTIUS AFP 235 Module (Table 1) and the adjusted parameters at nominal operating conditions (Table 2) simulations were realized in MATLABSimulink.

The results of the simulations are presented as $I-V$, $P-V$, and $P-I$ characteristics in Figures 5-16 for different solar irradiation, temperatures, series resistances, and parallel resistances.

Figures 5, 6, and 7 present the $I-V, P-V$, and $P-I$ characteristics for a constant temperature $\left(25^{\circ} \mathrm{C}\right)$ and for different solar radiations (from $200 \mathrm{~W} / \mathrm{m}^{2}$ to $1000 \mathrm{~W} / \mathrm{m}^{2}$ ). From Figure 5, with the increase of the solar radiation the current will increase as a result and from Figure 6 the voltage will increase, which will increase the generated power. Figures 8,9 , and 10 present the $I-V, P-V$, and $P-I$ characteristics for a constant radiation $\left(1000 \mathrm{~W} / \mathrm{m}^{2}\right)$ and for different temperatures of the environment (from $-20^{\circ} \mathrm{C}$ to $60^{\circ} \mathrm{C}$ ). It is to observed that, with the increasing of the temperature, the current will have a low increase while the voltage will decrease significantly. In this case the power delivered by the PV module will decrease significantly.

Figures 11, 12, and 13 present the $I-V, P-V$, and $P-I$ characteristics for a constant value of the parallel resistance $R_{p}=260 \Omega$, for different values for the series resistance $R_{s}\left(R_{s}=0.3 \Omega, R_{s}=0.9 \Omega\right.$, and $\left.R_{s}=1.5 \Omega\right)$, and for standard testing conditions STC $\left(1000 \mathrm{~W} / \mathrm{m}^{2}\right.$ and $\left.25^{\circ} \mathrm{C}\right)$. It is to observed that, for a high value of the resistances $R_{s}$, the results will be a decrease in the current and the voltage and, accordingly, a decrease in the generated power. This influence is better to observe near the Maximum Power Point, where both the Maximum Power and the fill factor
FF have low values. In this situation it is necessary to have a series resistance as low as possible, very close to zero value.

Figures 14, 15, and 16 present the $I-V, P-V$, and $P-I$ characteristics for a constant series resistance $R_{s}=0.3 \Omega$, for different values for the parallel resistance $R_{p}\left(R_{p}=260 \Omega, R_{p}=\right.$ $54 \Omega$, and $R_{p}=20 \Omega$ ), and for standard testing conditions STC $\left(1000 \mathrm{~W} / \mathrm{m}^{2}\right.$ and $\left.25^{\circ} \mathrm{C}\right)$. It is to observed that, for a low value of the parallel resistance, the results will be decreasing the value for the fill factor and power. For a better operation of the PV cell, it is necessary to have a parallel resistance as high as possible.

From all the above characteristics we can say that the energetical performances of the ALTIUS Module AFP-235W have optimal values when the series resistance is $R_{s}=0.3 \Omega$ and the parallel resistance is $R_{p}=260 \Omega$, for a solar radiation of $1000 \mathrm{~W} / \mathrm{m}^{2}$ and a temperature of the environment of $25^{\circ} \mathrm{C}$.

\section{Temperature Influence over the PV Module Performances}

The increase in the environment temperature and in the thermal radiation has a negative influence over the energetical performances of the PV system. To study these aspects, a thermal model of the ALTIUS Module AFP-235W using the finite element method was realized. The properties of the materials used on the module are presented in Table 3.

The photovoltaic panel is a capsuled system realized from many successive layers. Thus, it is necessary to have a high thermal conductivity in order to assure good cooling of the PV cells. Considering this construction in layers, the thermal transfer is realized between the layers by conduction, convection, and radiation. Thermal analysis by the finite element method supposes an establishment of the thermal equilibrium for every volume zone $d V$.

$$
P_{c}=P_{t}-P_{r}+P_{a}
$$

The left term of the equation is the heating power from the current flow, $P_{c}$. It is in balance with the heat stored by temporal change of temperature $P_{t}$, the power removed from the element by thermal conduction $P_{r}$, and the thermal power dissipated to the surrounding area by the surface convection, $P_{a}$. For $P_{c}, P_{t}, P_{r}$, and $P_{a}$, the following equations can be written: 
TABle 1: Parameters of the Altius, AFP 235 solar module at $25^{\circ} \mathrm{C}$, $1000 \mathrm{~W} / \mathrm{m}^{2}$ [25].

\begin{tabular}{lc}
\hline Name-specifications from data sheet & AFP 235 \\
\hline Maximum Power $($ Pmax, $e)$ & $239.99 \mathrm{Wp}$ \\
Voltage at Maximum Power $(V \mathrm{mp})$ & $29.6 \mathrm{~V}$ \\
Current at Maximum Power $(I \mathrm{mp})$ & $7.94 \mathrm{~A}$ \\
Open circuit voltage $(V \mathrm{oc})$ & $36.7 \mathrm{~V}$ \\
Short circuit current $(I \mathrm{sc})$ & $8.48 \mathrm{~A}$ \\
Maximum Power temperature coefficient & $-0.47 \% /{ }^{\circ} \mathrm{C}$ \\
Open circuit voltage temperature coefficient & $-0.32 \% /{ }^{\circ} \mathrm{C}$ \\
Short circuit current temperature coefficient & $+0.04 \% /{ }^{\circ} \mathrm{C}$ \\
Operating temperature & $-40 \sim+85^{\circ} \mathrm{C}$ \\
Nominal operating cell temperature (NOCT) & $45 \pm 2{ }^{\circ} \mathrm{C}$ \\
Number of cells $(N c)$ & 60 \\
\hline
\end{tabular}

$$
\begin{aligned}
& P_{c}=\iiint \rho j^{2} d V, \\
& P_{t}=\iiint \gamma c \frac{\partial \theta}{\partial t} d V, \\
& P_{r}=\iiint \operatorname{div}(\lambda \cdot \operatorname{grad} \theta) d V, \\
& P_{a}=\iiint k_{t} \frac{l}{S}\left(\theta-\theta_{a}\right) d V .
\end{aligned}
$$

Thus,

$$
\begin{aligned}
\iiint \rho j^{2} d V= & \iiint \gamma c \frac{\partial \theta}{\partial t} d V-\iiint \operatorname{div}(\lambda \cdot \operatorname{grad} \theta) d V \\
& +\iiint k_{t} \frac{l}{S}\left(\theta-\theta_{a}\right) d V
\end{aligned}
$$

The material density, specific heat, and thermal conductivity do not have an important temperature variation; thus they can be regarded as constants. On the other hand, the electrical resistivity has a significant temperature variation and can be estimated through a parabolic variation or a linear one. The experimental tests concluded that the difference between these two types of variation is not so important. For the electrical resistivity a linear variation with the temperature has been considered [32]:

$$
\rho=\rho_{0}\left[1+\alpha\left(\theta-\theta_{a}\right)\right]
$$

with the notation:

$$
\vartheta=\theta-\theta_{a} .
$$

Figure 17 shows the result of the thermal simulation for the ALTIUS Module AFP-235W for a nominal load of $235 \mathrm{~W}$ considered with a uniform distribution over the surface of the photovoltaic panel.

A temperature variation on the surface of the PV module is observed starting from a low temperature of $40.15^{\circ} \mathrm{C}$ to a high value of $52.07^{\circ} \mathrm{C}$ on the top of the surface of the PV
TABLE 2: Adjusted parameters of the Altius AFP 235 at nominal operating conditions.

\begin{tabular}{lc}
\hline Name-Specifications from data sheet & AFP 235 \\
\hline Maximum Power $(P \max , m)$ & $239.99 \mathrm{Wp}$ \\
Voltage at Maximum Power $(V \mathrm{mpp})$ & $29.6 \mathrm{~V}$ \\
Current at Maximum Power $(I \mathrm{mpp})$ & $7.94 \mathrm{~A}$ \\
Open circuit voltage $(V \mathrm{oc})$ & $36.7 \mathrm{~V}$ \\
Short circuit current $(I \mathrm{sc})$ & $8.48 \mathrm{~A}$ \\
Nominal saturation current $\left(I_{0, n}\right)$ & $3.65412 e-010 \mathrm{~A}$ \\
Photovoltaic current $\left(I_{\mathrm{pv}}\right)$ & $8.490576 \mathrm{~A}$ \\
Diode ideality factor $(a)$ & 1.3 \\
Series resistance $(R s)$ & $0.318 \Omega$ \\
Parallel resistance $(R p)$ & $259.398 \Omega$ \\
\hline
\end{tabular}

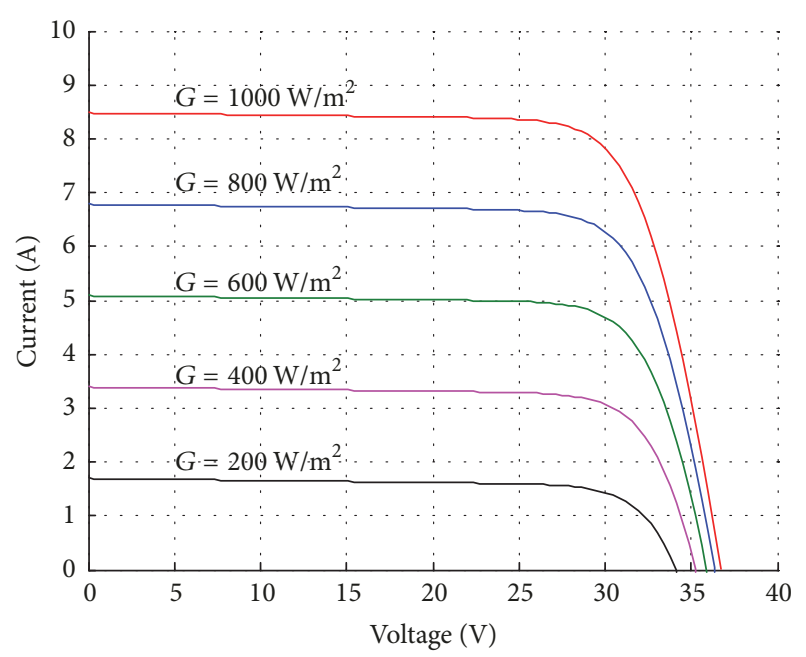

FIGURE 5: $I-V$ curves for different solar irradiation.

module. This is explained because of variable thermal convection coefficient. This coefficient includes the circulation of the air flow from the lower side of the panel to the top. It was considered only natural to cool of the PV module and for the temperature of the environment to be $25^{\circ} \mathrm{C}$.

\section{Experimental Data for the PV Module}

For the experimental analysis the photovoltaic panel ALTIUS Module AFP-235W was considered, oriented to the South and with an inclination of $45^{\circ}$. The experimental tests were realized on May 26, 2016 between 7.00 a.m. and 8 p.m. The solar irradiation was measured using a Solar Survey100/200R instrument, which is in compliance with the IEC-62446 international standard on PV systems. It measures the solar radiation to a maximum of $1500 \mathrm{~W} / \mathrm{m}^{2}$, with a resolution of $1 \mathrm{~W} / \mathrm{m}^{2}$. The temperature was measured with Extech 42545 IR thermometer (range: $50 \cdots 1000^{\circ} \mathrm{C}$, resolution: $0.1^{\circ} \mathrm{C}$ ). A digital multimeter Fluke 115 was used to measure the voltage and current (resolution of $1 \mathrm{mV}$ and $1 \mathrm{~mA}$ ). Figure 18 shows the evolution of the temperature of the environment, the 
TABLE 3: Properties of the materials used in AFP 235 module.

\begin{tabular}{lccccc}
\hline & Material & Thickness $[\mathrm{mm}]$ & Thermal conductivity, $[\mathrm{W} / \mathrm{mK}]$ & Density $\left[\mathrm{kg} / \mathrm{m}^{3}\right]$ & Specific heat $[\mathrm{J} / \mathrm{kgK}]$ \\
\hline 1 & Glass window & 3.2 & 1.7 & 3000 & 780 \\
2 & EVA film & 1 & 0.235 & 960 & 3135 \\
3 & PV cell & 0.22 & 148 & 2330 & 710 \\
4 & White Polyester & 1 & 0.25 & 1300 & 1350 \\
\hline
\end{tabular}

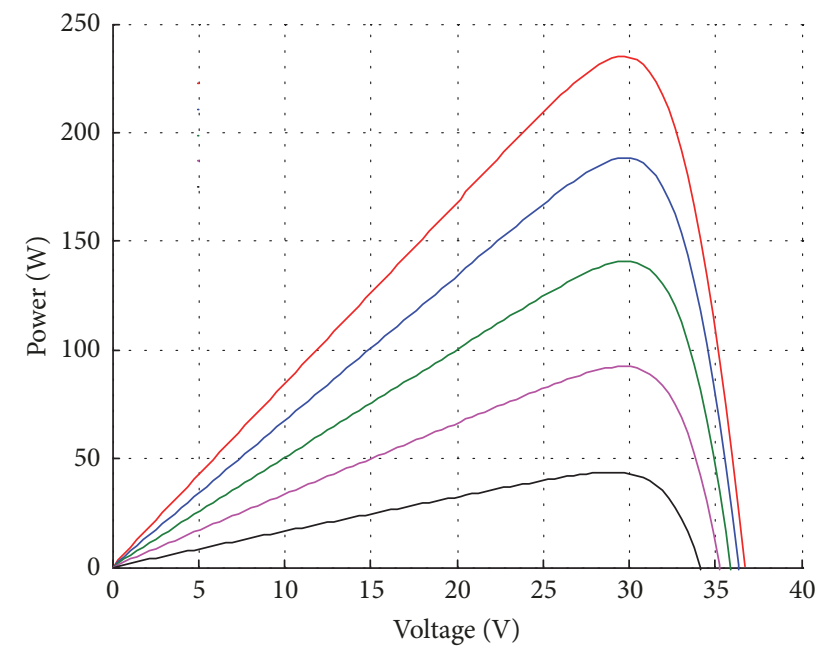

$$
\begin{aligned}
& -G=1000 \mathrm{~W} / \mathrm{m}^{2}-G=400 \mathrm{~W} / \mathrm{m}^{2} \\
& -G=800 \mathrm{~W} / \mathrm{m}^{2} \quad-G=200 \mathrm{~W} / \mathrm{m}^{2} \\
& -G=600 \mathrm{~W} / \mathrm{m}^{2}
\end{aligned}
$$

FIgURE 6: $P-V$ curves for different solar irradiation.

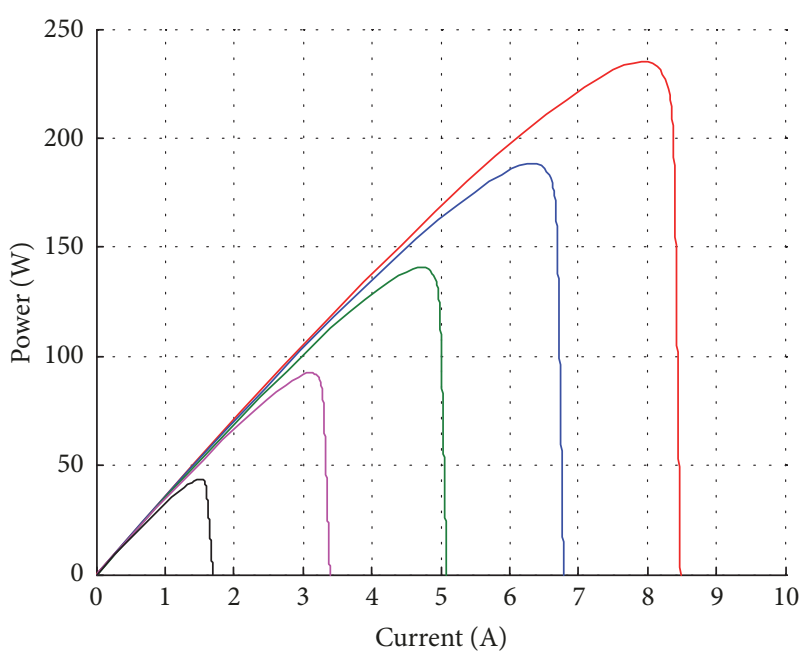

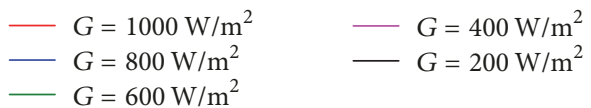

Figure 7: $P$-I curves for different solar irradiation.

temperature on the surface of the photovoltaic module, and the solar irradiation variation along the day. As the solar irradiation increases and is absorbed at the PV module surface, its temperature is increasing due to the photons absorption. At the maximum temperature of the environment of $28.3^{\circ} \mathrm{C}$

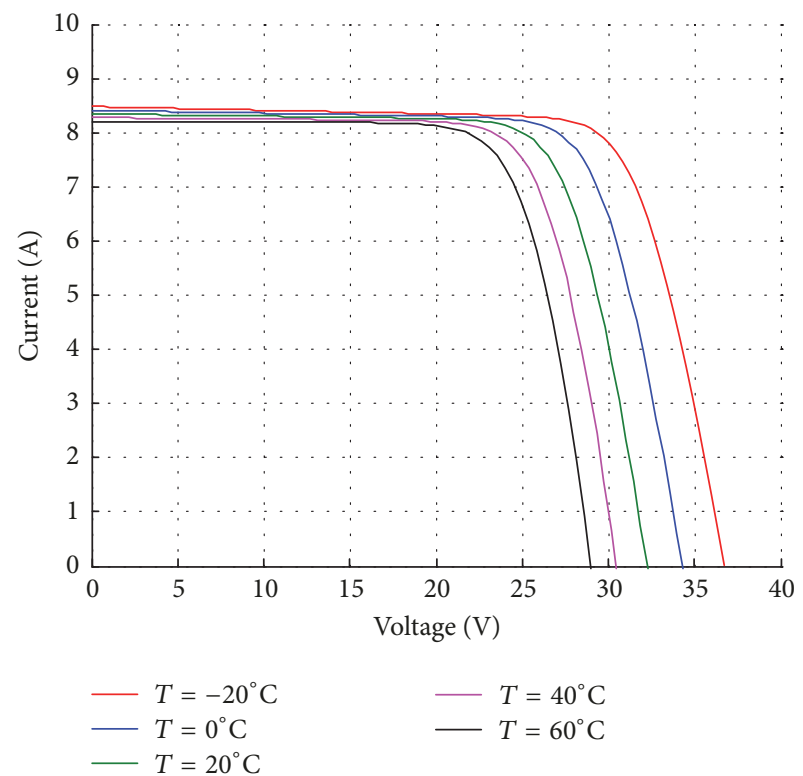

Figure 8: $I-V$ curves for different cell temperatures.

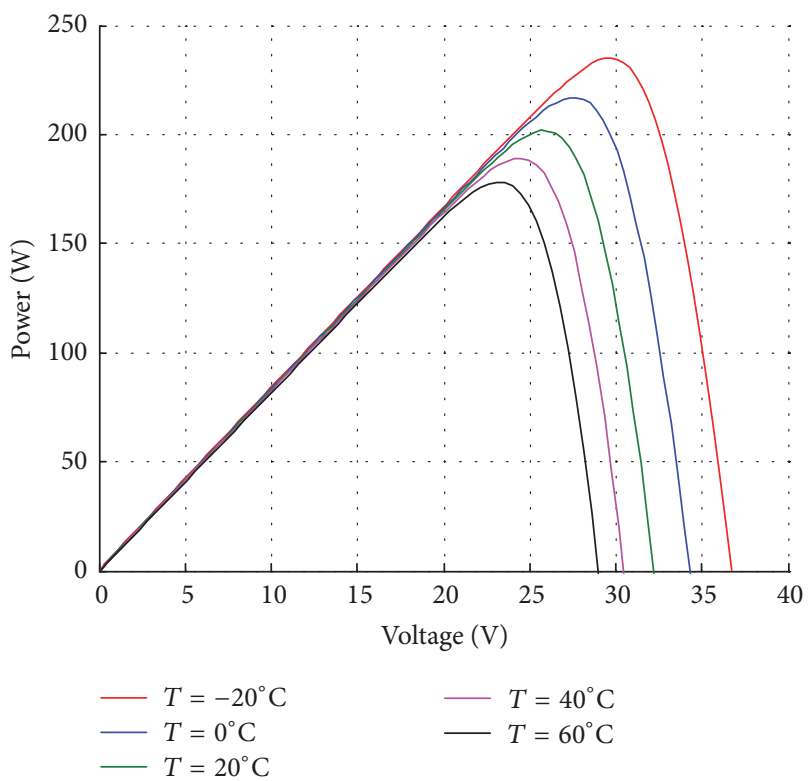

Figure 9: $P-V$ curves for different cell temperatures.

and a solar irradiation of $672 \mathrm{~W} / \mathrm{m}^{2}$, the temperature of the module surface reaches the value of $41.1^{\circ} \mathrm{C}$.

In Figures 19, 20, and 21 the simulated and experimental $I-V, P-V$, and, respectively, $P-I$ characteristics for the module PFV ALTIUS 235W for a medium temperature of $25^{\circ} \mathrm{C}$ and a 


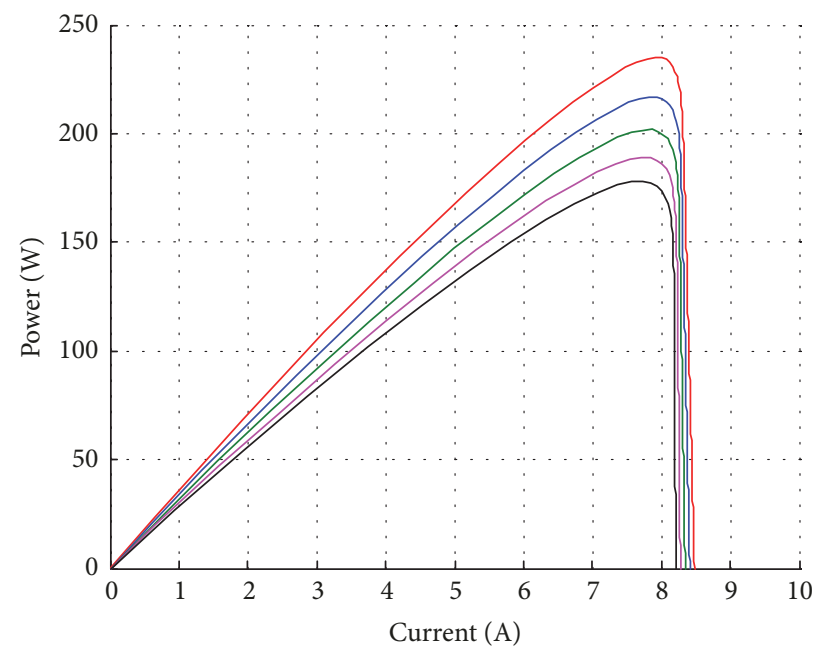

$$
\begin{array}{rlrl}
T & =-20^{\circ} \mathrm{C} & -T & =40^{\circ} \mathrm{C} \\
T & =0{ }^{\circ} \mathrm{C} & T & =60^{\circ} \mathrm{C} \\
T & =20^{\circ} \mathrm{C} & &
\end{array}
$$

Figure 10: $P-I$ curves for different cell temperatures.

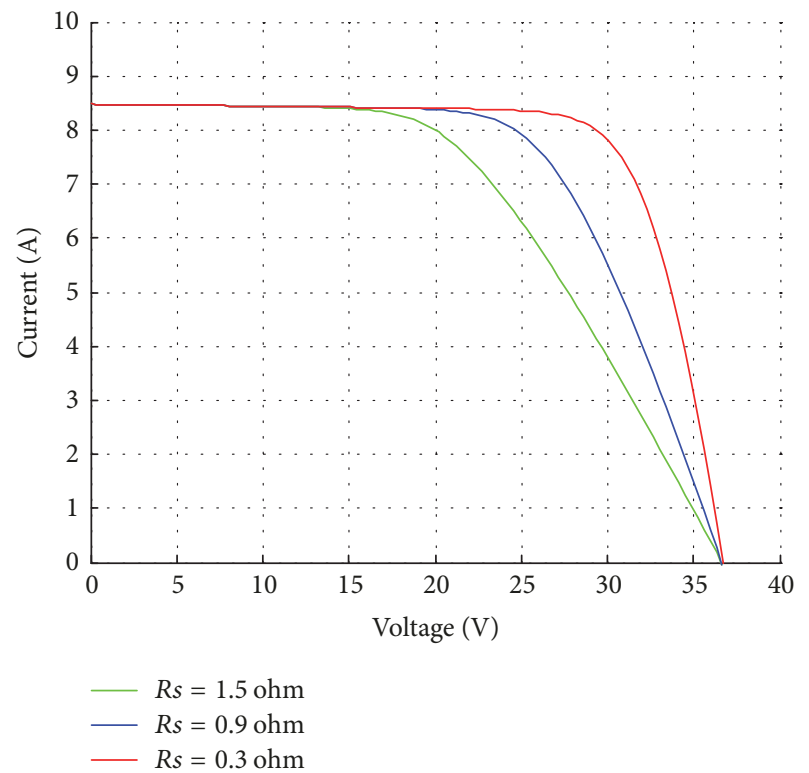

Figure 11: $I-V$ curves for different $R_{\mathrm{s}}$.

solar irradiation of $800 \mathrm{~W} / \mathrm{m}^{2}$ are plotted. The value of the nominal short circuit current is of $I_{\text {sc,exp }}=8.35 \mathrm{~A}$ for the experimental data and of $I_{\mathrm{sc}, \mathrm{sim}}=8.48 \mathrm{~A}$ for the simulation, with an error of $1.55 \%$. The nominal open circuit voltage is of $V_{0 c, \exp }=33.91 \mathrm{~V}$ for the experimental characteristic and $V_{\mathrm{oc}, \operatorname{sim}}=36.33 \mathrm{~V}$ for the simulated one, with an error of $-2,6 \%$. In the Maximum Power Point the experimental values for the voltage and current are $V_{\text {mpp,exp }}=27.79 \mathrm{~V}, I_{\text {mpp,exp }}=$ $6.628 \mathrm{~A}$, and a power of $P_{\text {mpp,exp }}=184.92 \mathrm{~W}$, while the simulated resulted values are $V_{\mathrm{mpp}, \mathrm{sim}}=25.55 \mathrm{~V}, I_{\mathrm{mpp}, \text { sim }}=$ $7.55 \mathrm{~A}$, and a power of $P_{\mathrm{mpp}, \mathrm{sim}}=192.9 \mathrm{~W}$. The error for the power estimation is about $4.3 \%$. In these characteristics there

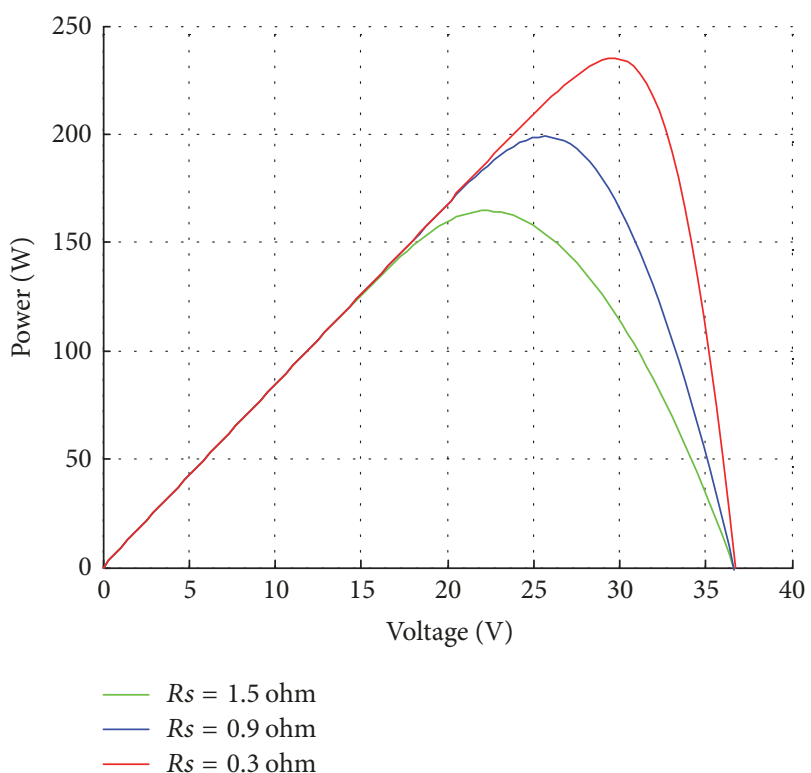

FIgURe 12: $P-V$ curves for different $R_{s}$.

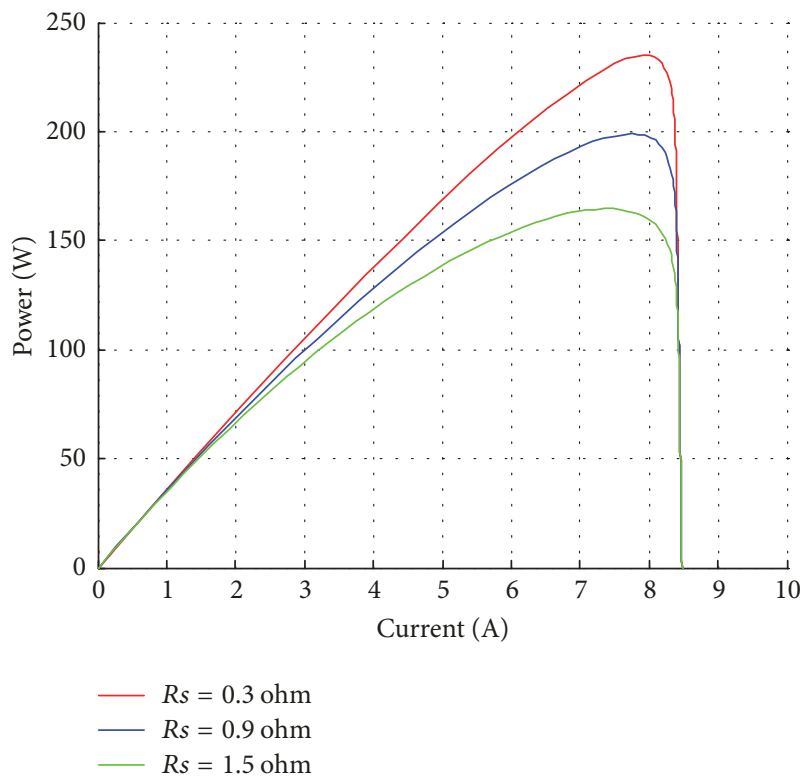

Figure 13: $P$ - $I$ curves for different $R_{\mathrm{s}}$.

are some differences between the simulated and the experimental data. For example on the point $\left(I_{s c, n}\right)$, there is a difference of $0.13 \mathrm{~A}$, on the point $\left(V_{0 c, n}\right)$, there is a difference of $2.42 \mathrm{~V}$, and on the MPP point, there is a difference of $2.24 \mathrm{~V}$ and $0.982 \mathrm{~A}(7.98 \mathrm{~W})$. These differences are due to the variation of the real temperature of the environment, of the solar irradiation, and consequently to the surface panel heating. Also the dust deposited on the panel surface and the wind has an important influence over the experimental data and thus on the difference between the simulated data and the experimental ones. 


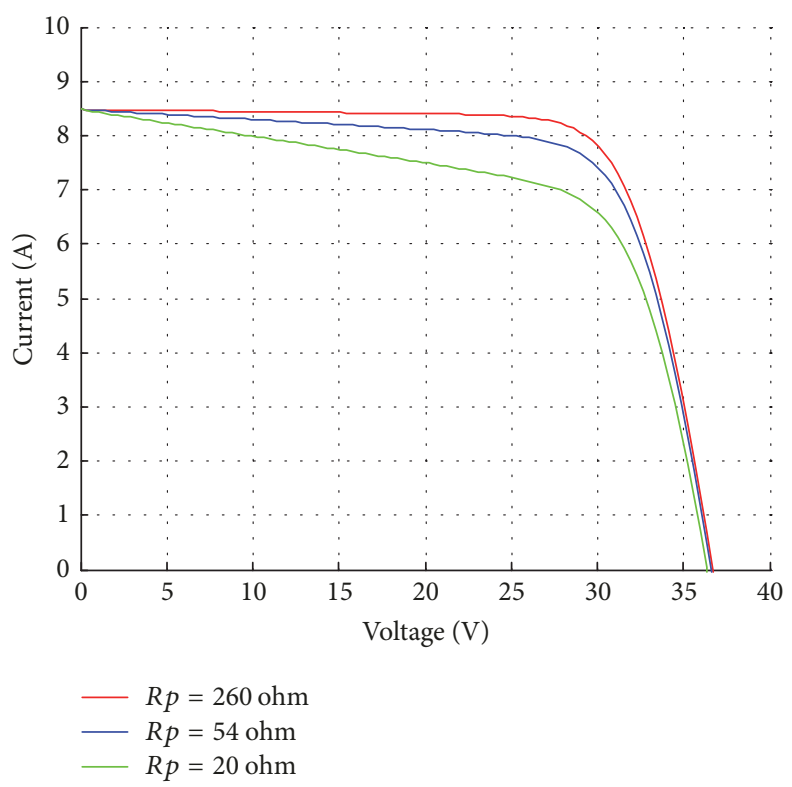

FIGURE 14: $I-V$ curves for different $R_{\mathrm{p}}$.

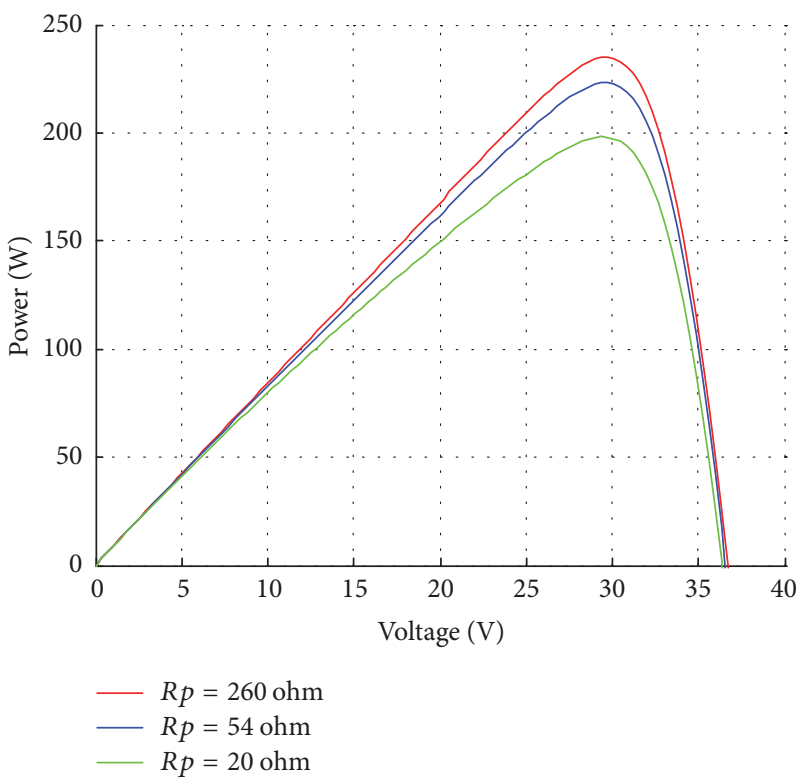

Figure 15: $P-V$ curves for different $R_{\mathrm{p}}$.

\section{Conclusions}

In this article a model of the photovoltaic module is developed and the influences of some parameters are analyzed as series and parallel resistances, temperature, and solar irradiation over the PV module output characteristics $(I-V$, $P-V$ and $P-I$ characteristics). For a real photovoltaic module (ALTIUS Module AFP-235W) there are estimated series and parallel resistances for which the energetical performances of the module have optimal values for a solar radiation of $1000 \mathrm{~W} / \mathrm{m}^{2}$ and a temperature of the environment of $25^{\circ} \mathrm{C}$. Temperature influence over the PV module performances is

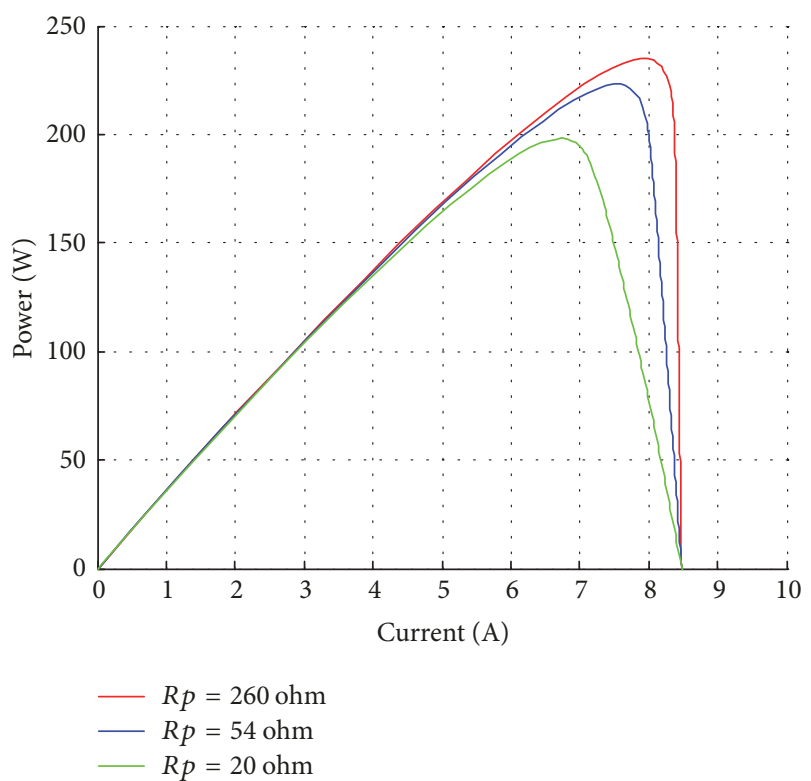

Figure 16: $P$ - $I$ curves for different $R_{\mathrm{p}}$.

analyzed by using a thermal model of the ALTIUS Module AFP-235W using the finite element method. A temperature variation on the surface of the PV module is estimated as a difference of about $12^{\circ} \mathrm{C}$ between the bottom and the top surface of the PV module. Experimental data are measured for the photovoltaic ALTIUS Module AFP-235W for an entire daylight. Differences between the simulated and recorded data are due to the variation of the real temperature of the environment, of the solar irradiation, and consequently to the surface panel heating. The dust deposited on the panel surface and the wind has an important influence over the 


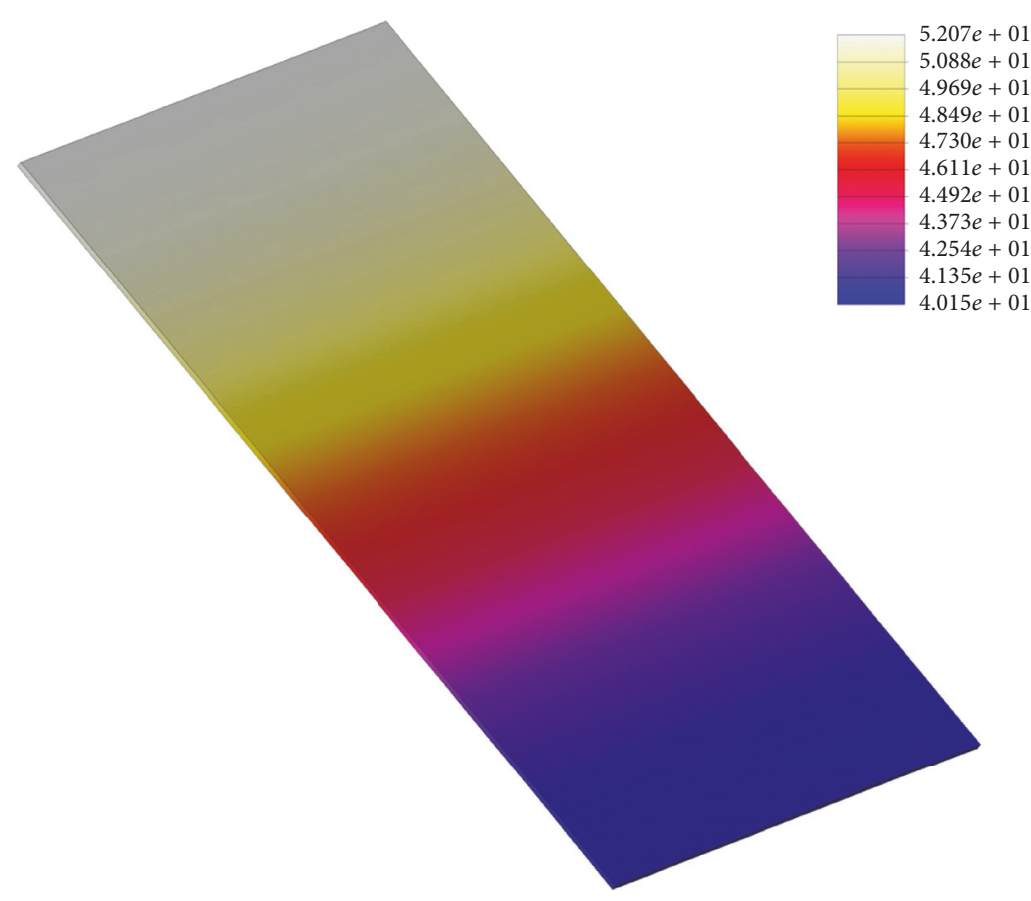

FIgURE 17: The temperature distribution for the PV module ALTIUS 235W.

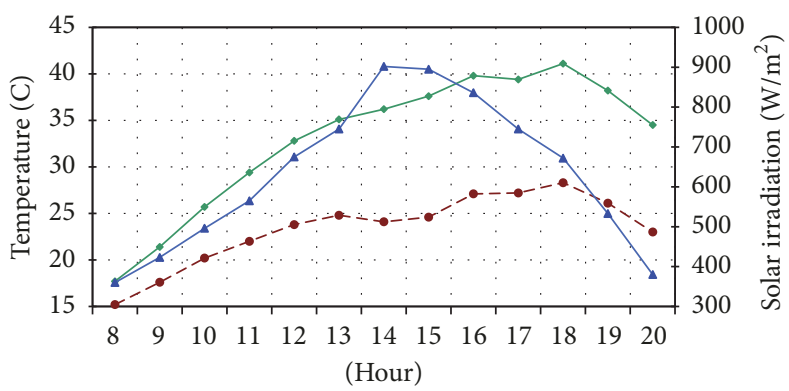

-- Ambient temperature
$\longrightarrow-$ Module temperature
$\longleftarrow$ Solar irradiation

FigURE 18: The $T-t-G$ experimental characteristics for PFV ALTIUS 235W.

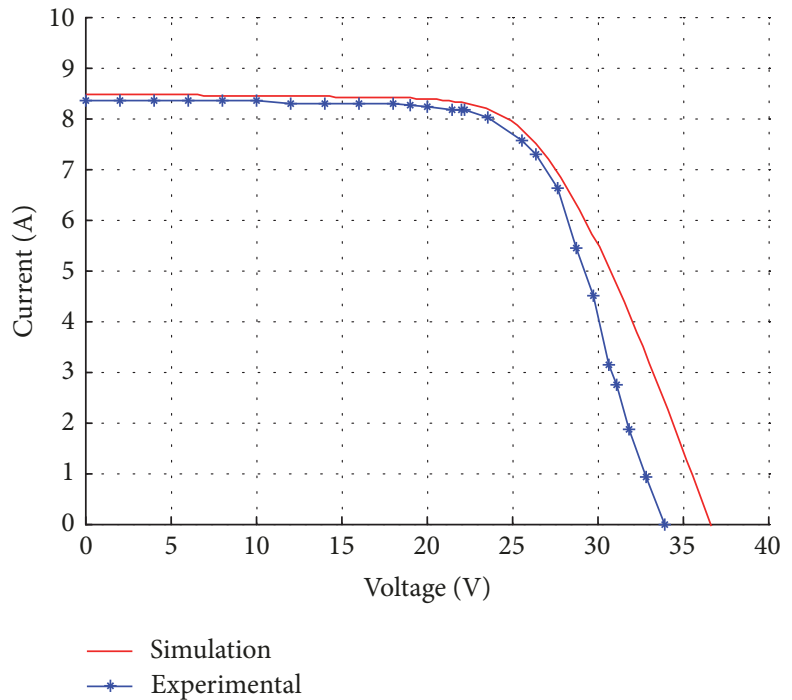

FIGURE 19: The $I$ - $V$ characteristics of PFV ALTIUS 235W. 


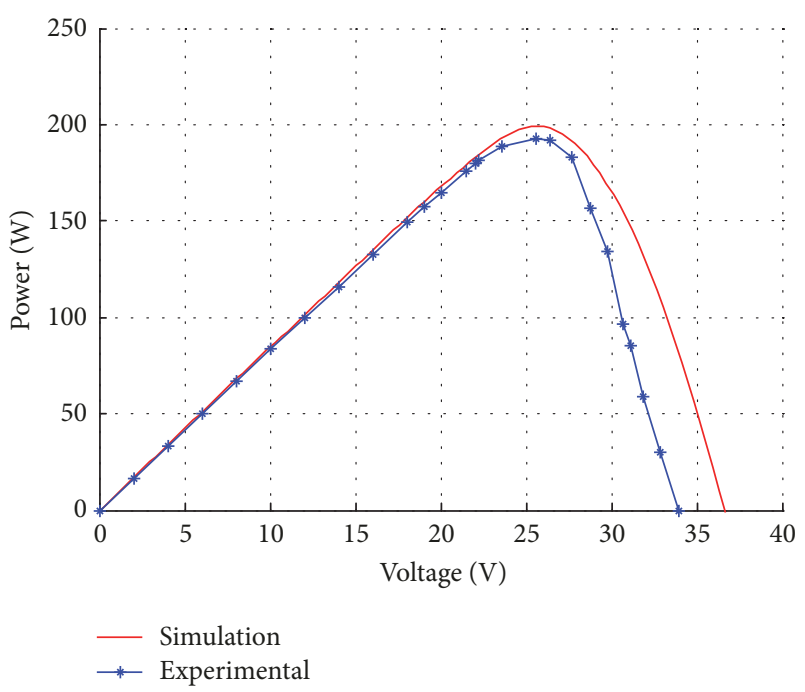

Figure 20: The $P-V$ characteristics of PFV ALTIUS 235W.

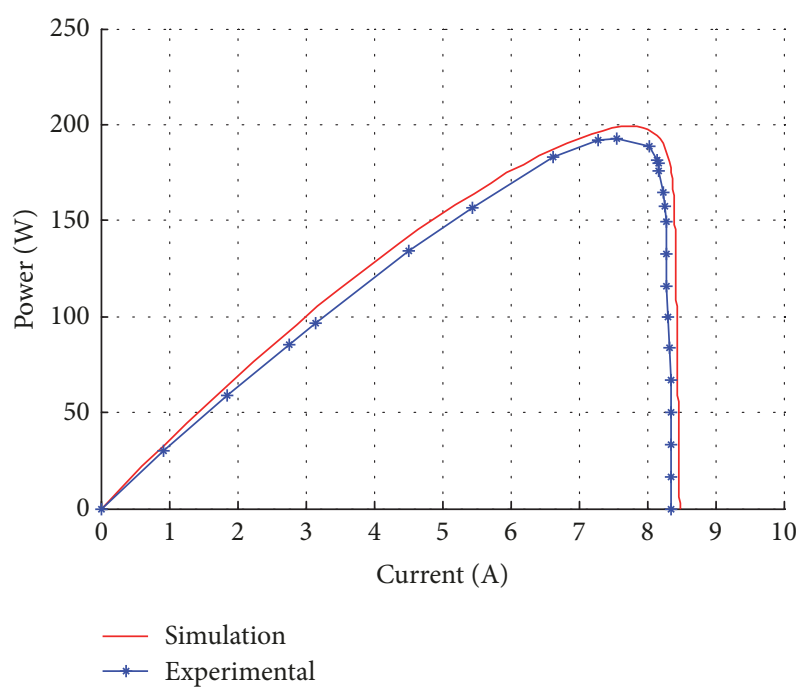

FIgUre 21: The $P-I$ characteristics of PFV ALTIUS 235W.

experimental data and thus on the difference between the simulated data and the experimental ones.

\section{Nomenclature}

$A_{\text {cell }}$ : The surface of the cell

$a$ : The ideality factor of the diode, $1 \leq a \leq 1.5$

$c$ : Specific heat

$G$ : The incident irradiation

$G_{n}$ : The nominal irradiation (usually $1000 \mathrm{~W} / \mathrm{m}^{2}$ )

$I_{0}$ : The reverse saturation current of the diode
$I_{0, n}: \quad$ The nominal saturation current

$I_{D}: \quad$ The diode current

$I_{\text {mpp }}$ : The current at the MPP point

$I_{\mathrm{pv}}$ : The photovoltaic current of the PV cell

$I_{\mathrm{pv}, n}: \quad$ The photovoltaic current at nominal irradiation and temperature

$I_{\mathrm{sc}, n}: \quad$ The nominal short circuit current

$j: \quad$ Current density

$K_{V}$ : The open circuit voltage temperature coefficient of the module

$K_{I}$ : The short circuit current temperature coefficient of the module

$k$ : The Boltzmann constant

$k_{t}: \quad$ Total transfer coefficient

$l$ : $\quad$ Perimeter length of the external surface

MPP: $\quad$ Maximum Power Point

$N_{p}$ : The number of the cells connected in parallel

$N_{s}: \quad$ The number of the cells connected in series

$P_{a}: \quad$ The thermal power dissipated to the environment area by the surface convection

$P_{c}: \quad$ The heating power from the current flow

$P_{\max , e}: \quad$ The maximum experimental power

$P_{\max , m}: \quad$ The maximum calculated peak output power

$P_{r}: \quad$ The power removed from the element by thermal conduction

$P_{t}$ : The heat stored by temporal change of temperature

$q$ : $\quad$ The electron charge

$R_{p}$ : The equivalent parallel resistance of the module

$R_{s}$ : The equivalent series resistance of the module

S: $\quad$ Surface convection

$T: \quad$ The ambient temperature

$T_{m}: \quad$ The nominal temperature (usually $25^{\circ} \mathrm{C}$ )

$V: \quad$ The open circuit voltage

$V_{0 c, n}: \quad$ The nominal open circuit voltage of the module

$V_{T}: \quad$ The thermal voltage of the module

$V_{\text {mpp }}: \quad$ The voltage at the MPP

$\alpha: \quad$ Coefficient of electrical resistivity variation with temperature

$\gamma: \quad$ Material density

$\lambda$ : Thermal conductivity

$\rho: \quad$ Electrical resistivity

$\rho_{0}$ : $\quad$ Electrical resistivity at the $\theta_{a}$ temperature

$\theta: \quad$ Temperature

$\theta_{0}$ : The initial temperature of the photovoltaic module

$\theta_{a}: \quad$ The temperature of the environment

$\vartheta=\theta-\theta_{a}:$ As notation.

\section{Conflicts of Interest}

The authors declare that they have no conflicts of interest. 


\section{References}

[1] R. Kumar and R. Muralidharan, "Mathematical modeling, simulation and validation of photovoltaic cells," International Journal of Research in Engineering and Technology, vol. 3, no. 10, pp. 170-174, 2014.

[2] T. Ahmad, S. Sobhan, and M. F. Nayan, "Comparative analysis between single diode and double diode model of PV cell: concentrate different parameters effect on its efficiency," Journal of Power and Energy Engineering, vol. 04, no. 03, pp. 31-46, 2016.

[3] H.-L. Tsai, C.-S. Tu, and Y.-J. Su, "Development of generalized photovoltaic model using MATLAB/Simulink," in Proceedings of the World Congress on Engineering and Computer Science, pp. 1-6, San Francisco, Calif, USA, 2008.

[4] B. Habbati, Y. Ramdani, and F. Moulay, "A detailed modeling of photovoltaic module using MATLAB," NRIAG Journal of Astronomy and Geophysics, vol. 3, pp. 53-61, 2014.

[5] M. G. Villalva, J. R. Gazoli, and E. R. Filho, "Modeling and circuit-based simulation of photovoltaic arrays," Brazilian Journal of Power Electronics, vol. 14, no. 1, pp. 35-45, 2009.

[6] Y. T. Tan, D. S. Kirschen, and N. Jenkins, "A model of PV generation suitable for stability analysis," IEEE Transactions on Energy Conversion, vol. 19, no. 4, pp. 748-755, 2004.

[7] A. Dev and B. Jeyaprabha, "Modeling and simulation of photovoltaic module in MATLAB," in Proceedings of the International Conference on Applied Mathematics and Theoretical Computer Science, pp. 268-273, 2013.

[8] A. M. Haque, S. Sharma, and D. Nagal, "Simulation of photovoltaic array using MATLAB/Simulink: analysis, comparison \& results," International Journal of Advanced Computer Technology, vol. 3, no. 2, pp. 12-21, 2016.

[9] J. Park, H. Kim, Y. Cho, and C. Shin, "Simple modeling and simulation of photovoltaic panels using Matlab/Simulink," Advanced Science and Technology Letters, vol. 73, pp. 147-155, 2014.

[10] S. Sumathi, A. L. Kumar, and P. Surekha, Solar PV and Wind Energy Conversion Systems. An Introduction to Theory, Modeling with MATLAB/Simulink, and the Role of Soft Computing Techniques, Green Energy and Technology, Springer, New York, NY, USA, 2015.

[11] N. D. Benavides and P. L. Chapman, "Modeling the effect of voltage ripple on the power output of photovoltaic modules," IEEE Transactions on Industrial Electronics, vol. 55, no. 7, pp. 2638-2643, 2008.

[12] A. Kajihara and T. Harakawa, "Model of photovoltaic cell circuits under partial shading," in Proceedings of the IEEE International Conference on Industrial Technology (ICIT'05), pp. 866-870, Hong Kong, China, December 2005.

[13] A. N. Celik and N. Acikgoz, "Modelling and experimental verification of the operating current of mono-crystalline photovoltaic modules using four- and five-parameter models," Applied Energy, vol. 84, no. 1, pp. 1-15, 2007.

[14] L. Cristaldi, M. Faifer, M. Rossi, and S. Toscani, "An improved model-based maximum power point tracker for photovoltaic panels," IEEE Transactions on Instrumentation and Measurement, vol. 63, no. 1, pp. 63-71, 2014.

[15] M. Veerachary, "PSIM circuit-oriented simulator model for the nonlinear photovoltaic sources," IEEE Transactions on Aerospace and Electronic Systems, vol. 42, no. 2, pp. 735-740, 2006.

[16] I. H. Altas and A. M. Sharaf, "A photovoltaic array simulation model for matlab-simulink GUI environment," in Proceedings of the International Conference on Clean Electrical Power (ICCEP '07), pp. 341-345, Capri, Italy, May 2007.

[17] E. Matagne, R. Chenni, and R. El Bachtm, "A photovoltaic cell model based on nominal data only," in Proceedings of the International Conference on Power Engineering, Energy and Electrical Drives (POWERENG '07), pp. 562-565, Setubal, Portugal, April 2007.

[18] Y. Lee and A. A. O. Tay, "Finite element thermal analysis of a solar photovoltaic module," Energy Procedia, vol. 15, pp. 413420, 2012.

[19] W. Z. Leow, Y. M. Irwan, M. Irwanto, M. Isa, A. R. Amelia, and I. Safwati, "Temperature distribution of three-dimensional photovoltaic panel by using finite element simulation," International Journal on Advanced Science, Engineering and Information Technology, vol. 6, no. 5, pp. 607-612, 2016.

[20] N. Boulfaf and J. Chaoufi, "Identification of thermal parameters of a solar photovoltaic panel in three-dimensional using finite element approach," International Journal of Renewable Energy Research, vol. 7, no. 2, pp. 578-584, 2017.

[21] F. Montero-Chacón, S. Zaghi, R. Rossi et al., "Multiscale thermo-mechanical analysis of multi-layered coatings in solar thermal applications," Finite Elements in Analysis and Design, vol. 127, pp. 31-43, 2017.

[22] A. Massi Pavan, S. Vergura, A. Mellit, and V. Lughi, "Explicit empirical model for photovoltaic devices. Experimental validation," Solar Energy, vol. 155, pp. 647-653, 2017.

[23] F. Sarhaddi, S. Farahat, H. Ajam, A. Behzadmehr, and M. Mahdavi Adeli, "An improved thermal and electrical model for a solar photovoltaic thermal (PV/T) air collector," Applied Energy, vol. 87, no. 7, pp. 2328-2339, 2010.

[24] J. Yazdanpanahi, F. Sarhaddi, and M. Mahdavi Adeli, "Experimental investigation of exergy efficiency of a solar photovoltaic thermal (PVT) water collector based on exergy losses," Solar Energy, vol. 118, pp. 197-208, 2015.

[25] Altius module high performance solar modules, AFP 60-250 Series/235-250W.

[26] D. Sera, R. Teodorescu, and P. Rodriguez, "PV panel model based on datasheet values," in Proceedings of the IEEE International Symposium on Industrial Electronics (ISIE '07), pp. 23922396, Vigo, Spain, June 2007.

[27] A. Driesse, S. Harrison, and P. Jain, "Evaluating the effectiveness of maximum power point tracking methods in photovoltaic power systems using array performance models," in Proceedings of the PESC 07 - IEEE 38th Annual Power Electronics Specialists Conference, pp. 145-151, Orlando, Fla, USA, June 2007.

[28] R. A. Messenger and J. Ventre, Photovoltaic Systems Engineering, CRC Press, Boca Raton, Fla, USA, 2004.

[29] J. Crispim, M. Carreira, and C. Rui, "Validation of photovoltaic electrical models against manufacturers data and experimental results," in Proceedings of the International Conference on Power Engineering, Energy and Electrical Drives, POWERENG 2007, pp. 556-561, Setubal, Portugal, April 2007.

[30] N. M. Abd Alrahim Shannan, N. Z. Yahaya, and B. Singh, "Single-diode model and two-diode model of PV modules: a comparison," in Proceedings of the 2013 IEEE International Conference on Control System, Computing and Engineering, ICCSCE 2013, pp. 210-214, Mindeb, Malaysia, December 2013. 
[31] V. Sangsawang and S. Chaitusaney, "Modeling of photovoltaic module from commercial specification in datasheet," in Proceedings of the 9th International Conference on Electrical Engineering/Electronics, Computer, Telecommunications and Information Technology, ECTI-CON 2012, Phetchaburi, Thailand, May 2012.

[32] A. T. Plesca, "Thermal analysis of the current path from circuit breakers using finite element method," International Journal of Electrical, Computer, Energetic, Electronic and Communication Engineering, vol. 6, no. 12, pp. 1479-1487, 2012. 


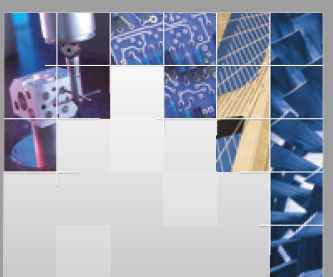

\section{Enfincering}
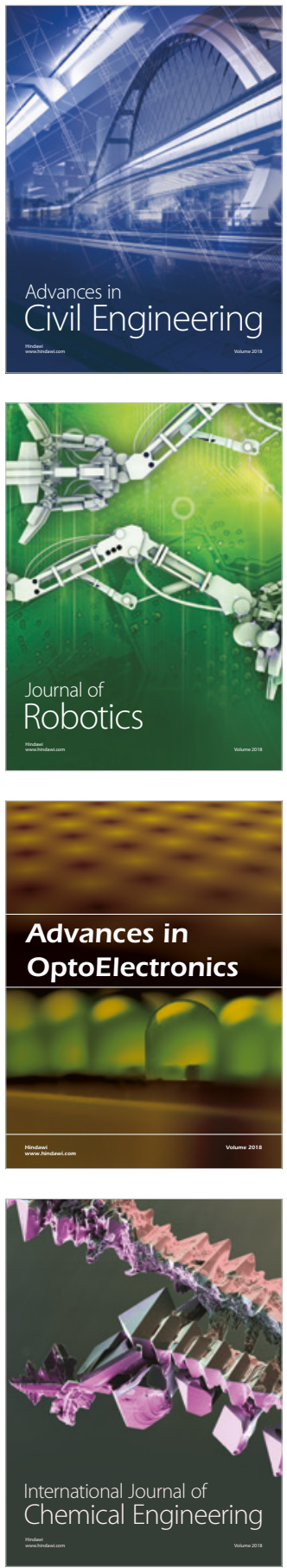

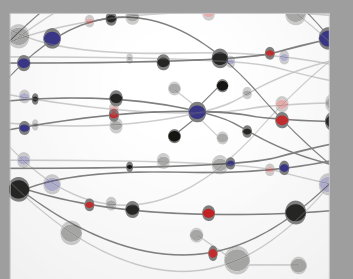

\section{Rotating \\ Machinery}

The Scientific World Journal

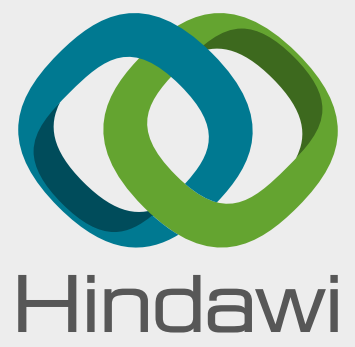

Submit your manuscripts at

www.hindawi.com
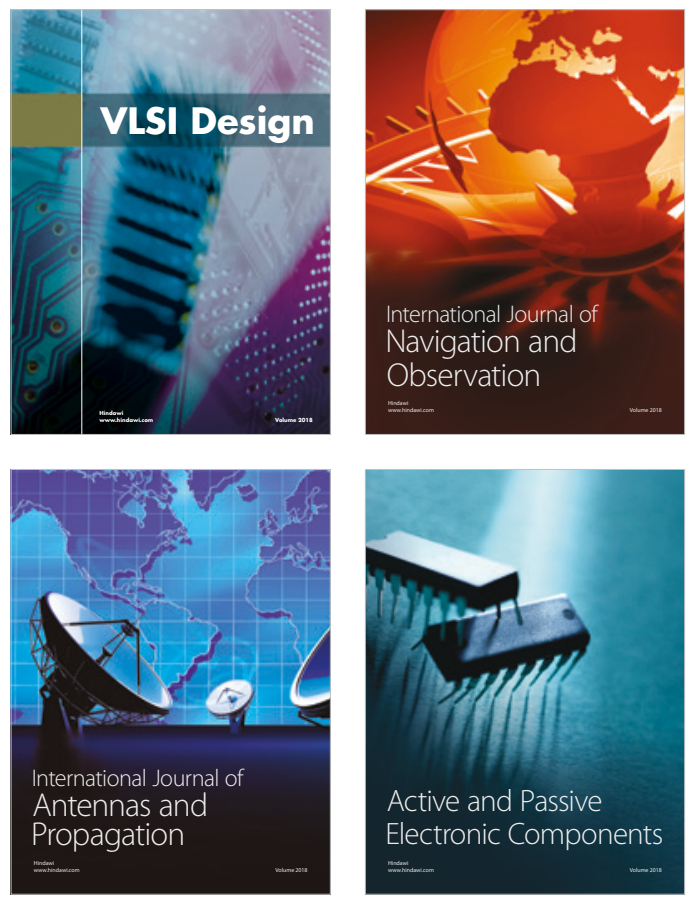
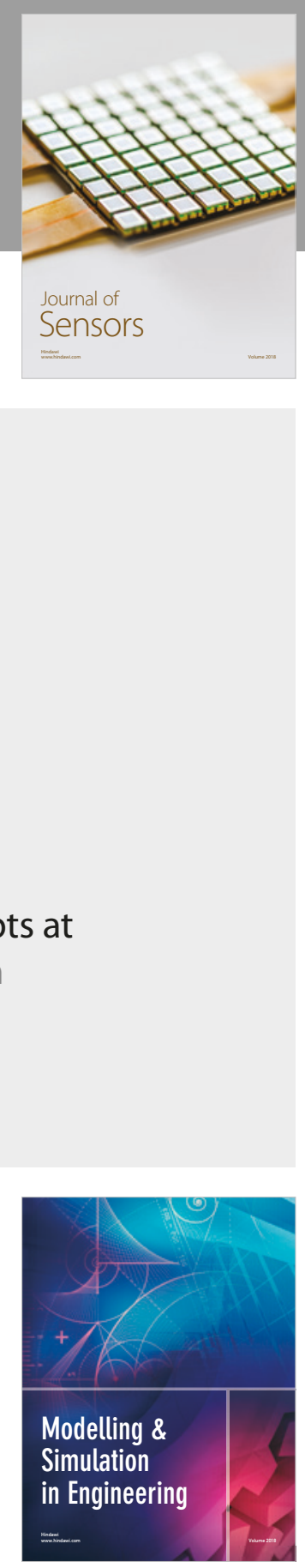

\section{Advances \\ Multimedia}
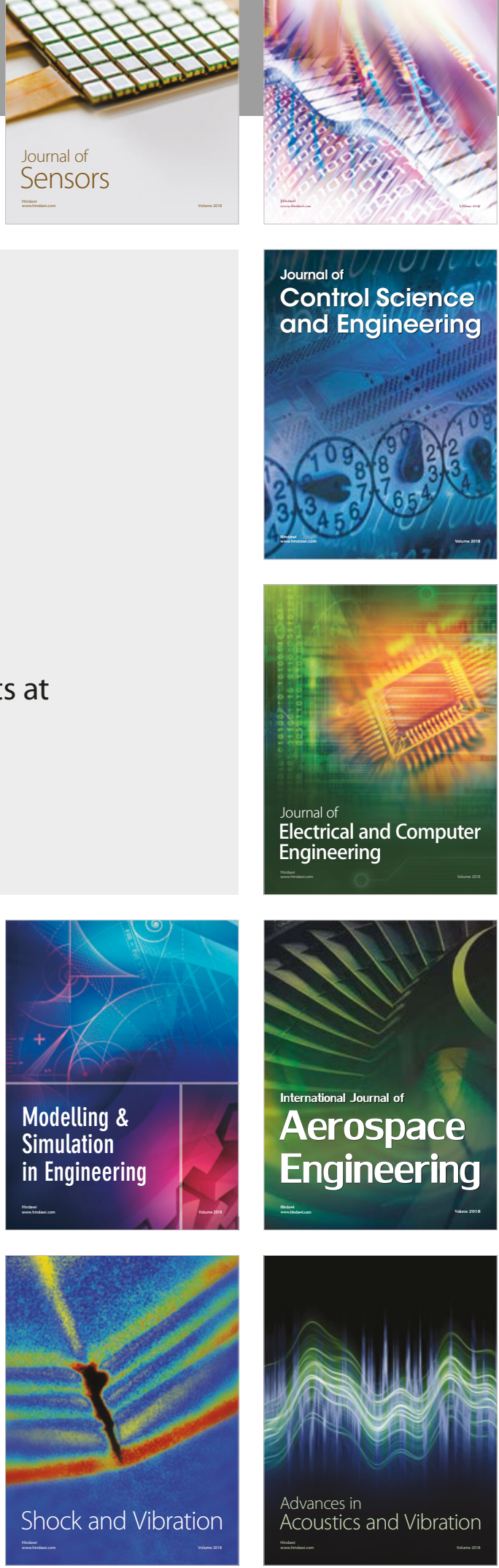